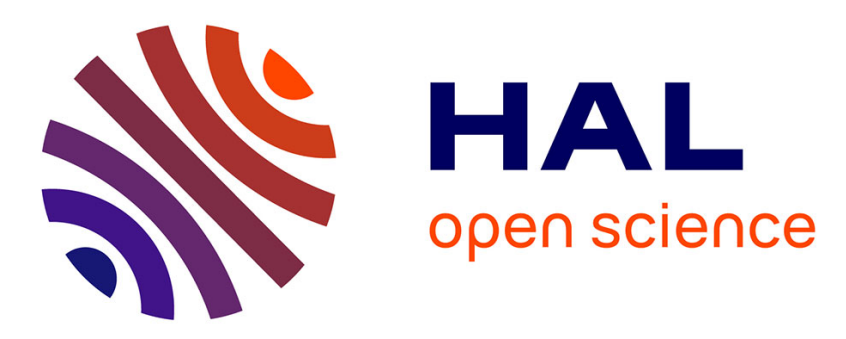

\title{
Altitude-induced responses observed in the control group
}

Grégoire P Millet, Franck Brocherie

\section{To cite this version:}

Grégoire P Millet, Franck Brocherie. Altitude-induced responses observed in the control group. Scandinavian Journal of Medicine and Science in Sports, 2018, 28 (10), pp.2243-2243. 10.1111/sms.13263 . hal-02544373

\section{HAL Id: hal-02544373 https://hal-insep.archives-ouvertes.fr/hal-02544373}

Submitted on 16 Apr 2020

HAL is a multi-disciplinary open access archive for the deposit and dissemination of scientific research documents, whether they are published or not. The documents may come from teaching and research institutions in France or abroad, or from public or private research centers.
L'archive ouverte pluridisciplinaire HAL, est destinée au dépôt et à la diffusion de documents scientifiques de niveau recherche, publiés ou non, émanant des établissements d'enseignement et de recherche français ou étrangers, des laboratoires publics ou privés. 
PROFESSOR GREGOIRE P MILLET (Orcid ID : 0000-0001-8081-4423)

Article type : Letter to Editor

Letter to the Editor

Scandinavian Journal of Medicine and Science in Sports.

\section{Altitude-induced responses observed in the control group.}

Grégoire P. Millet ${ }^{1}$, Franck Brocherie ${ }^{2}$

${ }^{1}$ Institute of Sports Sciences (ISSUL), University of Lausanne, Lausanne, Switzerland

${ }^{2}$ Laboratory Sport, Expertise and Performance (EA 7370), Research Department, French Institute of Sport (INSEP), 11 Avenue du Tremblay, Paris, France

Corresponding author:

Prof. Grégoire Millet

ISSUL, Institute of Sport Sciences, University of Lausanne, 1015, Lausanne, Switzerland.

Tel: +41216923294

Email: gregoire.millet@unil.ch 
Unfortunately, the experimental design did not allow testing their (surprising from a research group claiming for years that LHTL is not effective in endurance athlete ${ }^{2}$ ) hypothesis since there was no control group (i.e. not exposed to altitude). This conclusion is a perfect example of scientific bad faith. It could be concluded with the same bad faith that the so-called "control group" benefited from their moderate altitude (1000-1500 m) exposure (for both sleeping and training). By the way, there was only a small (3.3-2.7\% - Table 3) difference in SpO2 during sleeping time. It is therefore not so surprising to find similar responses between these two groups. Therefore, it is possible to suspect erythropoietic stimulation or altitude-induced physiological responses also in this "control" group exposed to a significant hypoxic dose (450 $\mathrm{km} . \mathrm{h}$ ). The time courses in plasma volume (acute change at return to sea-level for a transient period), Hbmass (continuous increase during the camp and maintained for at least 18-20 days), EPO (acute decrease at return to sea-level) are similar to the classically described responses following either LHTH or LHTL during the post-hypoxia period after return to sea-level (in this case, Lillehammer, 200m). Moreover the change in VO2max or test duration from PRE to POST1 (increase), POST2 (no change) and POST3 (increase) is in line with the assumptions of the coaches for this post-altitude period ${ }^{3}$. Finally, the delayed improvement (18-20 days in maximal aerobic speed and $3-\mathrm{km}$ performance fits perfectly with the recommended window ${ }^{3}$. The "control" post-altitude kinetics of many parameters was similar than the one observed in the LHTL group. In highly-trained endurance athlete, it makes no sense to explain these time courses only by training effects. In our view, it makes sense that the control group benefited from the moderate altitude exposure, explaining the no-difference observed with the LHTL group.

1. Robach P, Hansen J, Pichon A, et al. Hypobaric live high-train low does not improve aerobic performance more than live low-train low in cross-country skiers. Scand $J$ Med Sci Sports. Feb 222018.

2. Robach $\mathrm{P}$, Lundby $\mathrm{C}$. Is live high-train low altitude training relevant for elite athletes with already high total hemoglobin mass? Scand J Med Sci Sports. Jun 2012;22(3):303-305.

3. Chapman RF, Laymon Stickford AS, Lundby C, Levine BD. Timing of return from altitude training for optimal sea level performance. J Appl Physiol (1985). Apr 2014;116(7):837-843.

4. Millet GP, Chapman RF, Girard O, Brocherie F. Is live high-train low altitude training relevant for elite athletes? Flawed analysis from inaccurate data. Br J Sports Med. Dec 152017.

This article is protected by copyright. All rights reserved. 